\title{
РОЗРОБКА СПЕКТРОФОТОМЕТРИЧНОЇ МЕТОДИКИ ВИЗНАЧЕННЯ АТОРВАСТАТИНУ В ТАБЛЕТКАХ
}

Вступ. Аторвастатин - широко представлений на фрармацевтичному ринку України гіполіпідемічний засіб, який використовують при гіперліпідемії та для профрілактики захворювань серцево-судинної системи. Відомо багато методик кількісного визначення аторвастатину, однак багато з них має обмежене застосування через використання шкідлиих реагентів, довготривалість, нагрівання, необхідність екстракції тощо.

Мета дослідження - розробити з дотриманням принципів “зеленоі" хімії просту економічно ефективну УФ-спектрофотометричну методику визначення аторвастатину в лікарських засобах, які представлено на ринку України.

Mетоди дослідження. При виконанні цього дослідження застосовували спектрофротометр "Shimadzu UV-1800" (Японія), ваги лабораторні електронні “RAD WAG AS 200/C”, ультразвукову баню “Sonorex Digitec DT100H", мірний посуд класу A, фрармакопейний стандартний зразок аторвастатину кальцію тригідрат

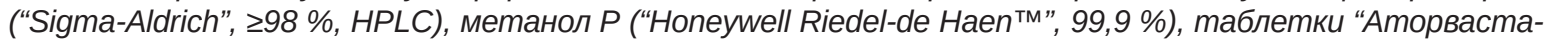
тин-Тева", 10 мг № 10 (“Теvа", Ізраїль), серія № 19939.

Результати й обговорення. Для опрацювання методики кількісного визначення аторвастатину методом прямої УФ-спектрофотометрії було обрано інтенсивно виражений максимум поглинання препарату при довжині хвилі 247 нм. Шляхом прогнозування повної невизначеності аналітичної методики підтверджено ії коректність (2,56 \%). Лінійну залежність отримано в діапазоні 8-40 мкг/мл, межа виявлення та межа кількісного визначення становили 0,5 і 1,6 мкг/мл відповідно. Специфічність методики доведено відсутністю смуг поглинання при аналітичній довжині хвилі у розчинів плацебо аналізованих таблеток. Прецизійність експериментальних результатів характеризувалася низьким стандартним відхиленням у досліджуваному діапазоні концентрацій активного фрармацевтичного інгредієнта $(R S D=3,1 \%)$, а систематична похибка була на рівні 0,02 \%. При вивченні робасності методики встановлено стабільність поглинання розчинів у часі впродовж 100 хв. За аналітичною еко-шкалою методика $\epsilon$ "Відмінним “зеленим" аналізом".

Висновки. Розроблено методику УФ-спектрофотометричного визначення кількісного вмісту аторвастатину в таблетках ( $\lambda_{\max }=247$ нм). Розраховано повну невизначеність розробленої методики. За такими валідаційними характеристиками, як лінійність, прецизійність, правильність та робасність, методика є коректною.

КЛЮЧОВІ СЛОВА: спектрофротометрія; аторвастатин; кількісне визначення; валідація; аналітична еко-шкала.

ВСТУП. Загальний асортимент гіполіпідемічних препаратів на ринку України представлений 90 торговими найменуваннями, з них 79,7 \% становлять статини [1]. Згідно з даними літературних джерел [2], найбільшою кількістю торгових найменувань серед них фрармацевтичний ринок України був забезпечений препаратами 3 МНH C10АА05 - Аторвастатин. Аторвастатин препарат III покоління, що чинить сильний гіполіпідемічний ефект, особливо у хворих із резистентністю до інших засобів та зі спадковою гі-

(ㄱ Н. С. Шуляк, С. А. Процик, Т. В. Кучер, Л. С. Криськів, 2021. перхолестеринемією. За хімічною будовою це (3R,5R)-7-[2-(4-Фторфененіл)-3-френіл-4-(фенілкарбамоіл)-5-пропан-2-іл-пірол-1-іл]-3,5-дигідроксигептанова кислота [3]. Європейська Фармакопея рекомендує проводити кількісне визначення вмісту активного фрармацевтичного інгредієнта в субстанції аторвастатину кальцію тригідрату (АТС) методом рідинної хроматографpiї [4]. У науковій літературі описано значну кількість методик кількісного визначення АТС у лікарських засобах та біологічних рідинах методами високоесрективної рідинної хроматограсії [5-9], хромато-мас-спектрометрії [10], раман- 
спектроскопії [11], спектросротометрії [9, 12-15], мас-спектрометрії [16] та електрохімічного визначення [17]. Відомі спектрофотометричні методики визначення ATC за утворенням іон-парних комплексів із сульфрафталеїновими барвниками [12], п-диметиламінобензальдегідом [13], п-розаніліном гідрохлоридом [14] та з використанням сечовини як гідротропного солюбілізувального агента [15]. Вказані методики мають ряд недоліків, це, зокрема, використання шкідливих реагентів, довготривалість, нагрівання, необхідність екстракції тощо. Пряма УФ-спектрофотометрія, завдяки простоті й значній економічності, все ще залишається найчастіше використовуваним аналітичним методом у фрармацевтичному аналізі [18].

Мета дослідження - розробити з дотриманням принципів "зеленої" хімії просту економічно есрективну УФ-спектросоотометричну методику визначення аторвастатину в лікарських засобах, які представлено на ринку України.

МЕТОДИ ДОСЛІДЖЕННЯ. При виконанні дослідження застосовували фрармакопейний стандартний зразок (ФСЗ) аторвастатину кальцію тригідрат ("Sigma-Aldrich", $\geq 98$ \%, HPLC), метанол Р ("Honeywell Riedel-de Haen 'M", 99,9\%), таблетки "Аторвастатин-Тева", 10 мг № 10 (“Teva”, Ізраїль), серія № 19939.

Поглинання розчинів в УФ-ділянці вимірювали у кварцових кюветах (1 см) проти метанолу P на двопроменевому скануючому спектрофотометрі "Shimadzu UV-1800" (Японія) з використанням програмного пакета UV-Probe 2.62. Застосовували ваги лабораторні електронні "RAD WAG AS 200/C", ультразвукову баню "Sonorex Digitec DT100H", мірний посуд класу А. Статистичну обробку та визначення валідаційних характеристик проводили відповідно до вимог ДФУ 2.0 [19] та ICH Q2 [20].
Приготування випробовуваного розчину таблеток аторвастатину: точну наважку порошку розтертих таблеток, еквівалентну 10 мг ATC, поміщають у мірну колбу місткістю 100 мл, додають 60 мл метанолу Р, нагрівають протягом 5-10 хв на водяній бані при температурі $50^{\circ} \mathrm{C}$, охолоджують і доводять об'єм розчину до позначки метанолом Р, перемішують та фрільтрують. У мірну колбу на 50 мл переносять 1,0 мл отриманого розчину, доводять об'єм розчину до позначки метанолом $\mathrm{P}$ і ретельно перемішують.

Приготування розчину ФСЗ аторвастатину: 10,0 мг ФСЗ АТС поміщають у мірну колбу місткістю 100 мл, додають 60 мл метанолу Р, розчиняють, доводять об'єм розчину до позначки метанолом Р та ретельно перемішують. У мірну колбу на 50 мл переносять 1,0 мл отриманого розчину, доводять об'єм розчину до позначки метанолом $\mathrm{P}$ і ретельно перемішують.

РЕЗУЛЬТАТИ Й ОБГОВОРЕННЯ. ЗаПроПОнована методика базується на прямому вимірюванні поглинання випробовуваних розчинів в УФ-ділянці відносно компенсаційного розчину. УФ-спектри ФСЗ АТС у метанолі й метанольного вилучення з таблеток аторвастатину мають інтенсивно виражені максимуми поглинання при 212 та 247 нм (рис. 1).

Для встановлення вмісту АТС вимірювали поглинання випробовуваного розчину при $\lambda_{\max }=$ 247 нм відносно компенсаційного розчину. Результати визначення вмісту АТС у препараті наведено в таблиці 1.

Валідацію аналітичної методики проводили за основними валідаційними характеристиками, такими, як: специсрічність, лінійність, діапазон застосування, межа виявлення (МВ) та межа кількісного визначення (МКВ), правильність, прецизійність, робасність.

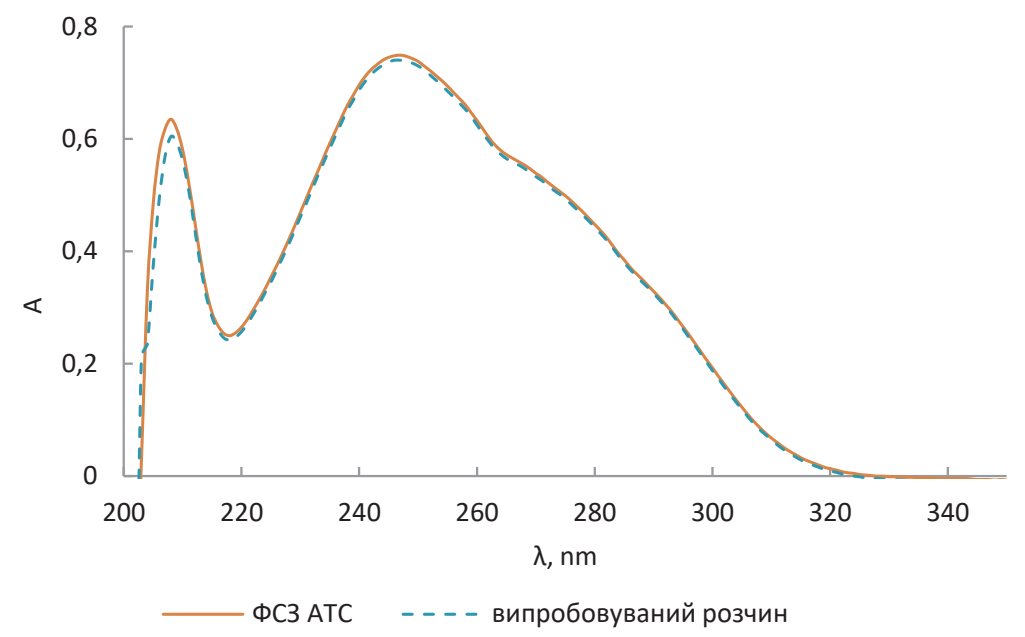

Рис. 1. Електронні спектри поглинання метанольних розчинів аторвастатину. С(АТС) = 20 мкг/мл. 
Таблиця 1 - Результати кількісного визначення аторвастатину в лікарському засобі $(n=6, p=0,95)$

\begin{tabular}{||c|c|c||}
\hline Лікарський засіб & Знайдено, г & Метрологічні характеристики \\
\hline Таблетки “Аторвастатин Тева", 10 мг & 0,0103 & $\bar{m}=0,0103$ г \\
& 0,0102 & $\mathrm{~S}=3,21 \times 10^{-3}$ \\
& 0,0099 & $t=2,57$ \\
& 0,0105 & $\Delta x=3,37 \times 10^{-3}$ \\
& 0,0107 & $\mathrm{RSD}=3,13$ \\
\hline
\end{tabular}

Прогнозування повної невизначеності методики

Для підтвердження коректності аналітичної методики проводять прогнозування повної невизначеності методики. Невизначеність кінцевої аналітичної операції для спектрофотометричного аналізу становить 0,70 \%. Розрахунок невизначеності пробопідготовки для кількісного визначення АТС у лікарському засобі наведено в таблиці 2.

Таблиця 2 - Розрахунок невизначеності пробопідготовки для кількісного визначення аторвастатину в лікарському засобі

\begin{tabular}{||l|c|c||}
\hline \multicolumn{1}{|c|}{ Операція пробопідготовки } & $\begin{array}{c}\text { Параметр розрахункової } \\
\text { формули }\end{array}$ & Невизначеність, \% \\
\hline \multicolumn{2}{|c||}{ Розчин порівняння АТС } \\
\hline 1) взяття наважки ФСЗ аторвастатину
\end{tabular}

3гідно 3 даними таблиці 2, невизначеність пробопідготовки $\left(\Delta_{A S}\right)$ для визначення АТС у лікарському засобі становить 2,46 \%. Розподіл невизначеності пробопідготовки за операціями для кількісного визначення АТС у лікарському засобі показує, що найбільшу невизначеність у пробопідготовку вносять операції 1, 7 - взяття наважки й аліквоти. Повна невизначеність аналітичної методики $\left(\triangle_{A S}\right)$ визначення АТС становить 2,56 \%:

$$
\Delta_{A s}=2,56 \% \leq \max \Delta_{A s}=3,2 \% .
$$

Отже, прогнозована повна невизначеність результатів аналізу не перевищувала критичних значень $\left(\max \Delta_{A s}\right)$. Це доводить, що розроблена спектрофотометрична методика буде давати коректні результати в інших лабораторіях.

Специфрічність методики

При реєстрації спектра розчину, отриманого 3 метанольного вилучення модельної таблетної суміші, що містила допоміжні речовини, і підготовленого аналогічно випробовуваному розчину, поглинання за довжини хвилі 212 та 247 нм не спостерігали, тобто плацебо аналізованих таблеток за умов кількісного визначення не дає смуг погли- нання, а отже, не впливає на поглинання розчину під час кількісного визначення АТС.

Лінійність, діапазон застосування методики

Лінійність вивчали на всьому діапазоні застосування методики з використанням модельних розчинів зразків відповідно до вимог ДФУ [19]. Отримані результати було оброблено за допомогою методу найменших квадратів для рівняння $y=a+b \cdot x$, де $y-$ поглинання; $x-$ концентрація визначуваної лікарської речовини; $a$-вільний член лінійної залежності; $b-$ кутовий коесріцієнт для розрахованої регресійної прямої. Електронні спектри поглинання метанольних розчинів АТС за умов вивчення лінійності аналітичної методики наведено на рисунку 2.

Встановлено лінійну залежність поглинання від концентрації АТС у діапазоні 8-40 мкг/мл (рис. 3).

Межу виявлення та межу кількісного визначення розраховували за стандартним відхиленням аналітичного сигналу $\sigma$ для зразків, що не містять визначуваної речовини, і тангенсом нахилу регресійної прямої $b, \mathrm{MB}=3,3 \sigma / b$, 


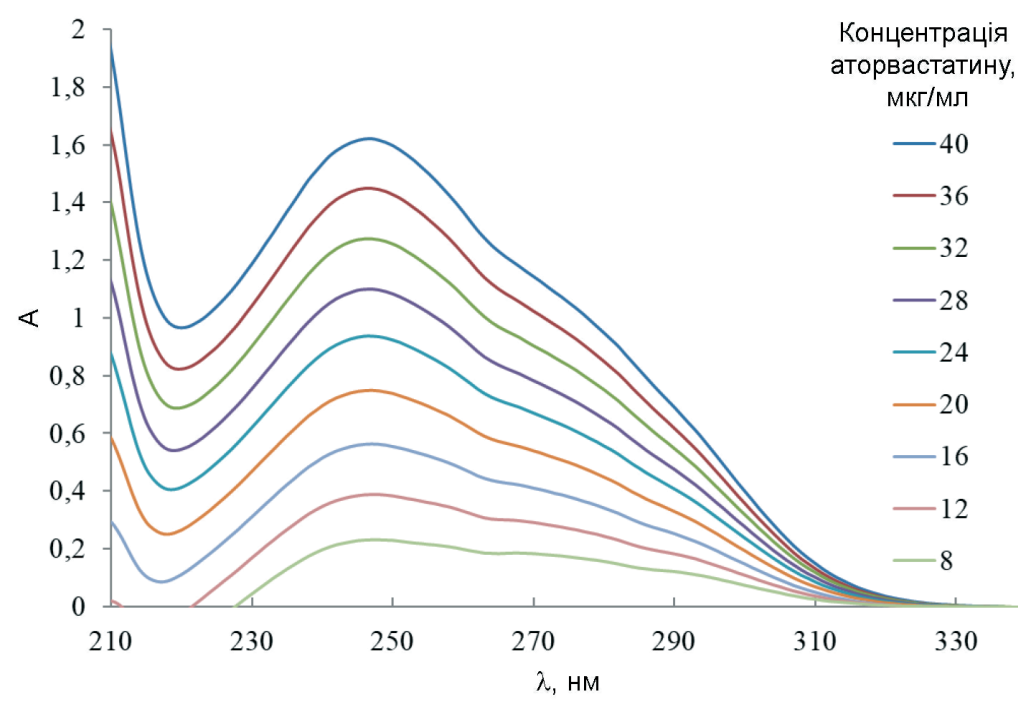

Рис. 2. Електронні спектри поглинання метанольних розчинів аторвастатину за умов вивчення лінійності аналітичної методики.

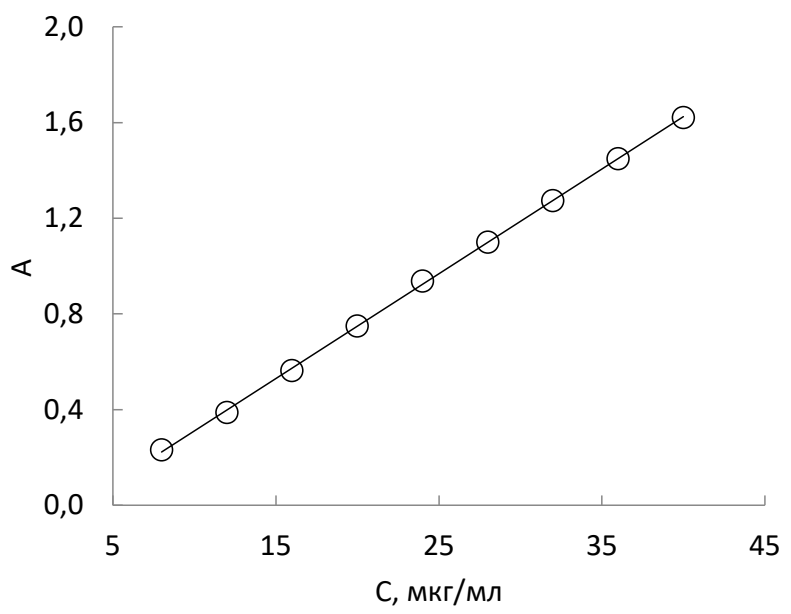

Рис. 3. Грасрік залежності поглинання від концентрації аторвастатину.

МкВ $=10 \sigma / b$. Межа виявлення та межа кількісного визначення становлять 0,5 і 1,6 мкг/мл відповідно.

Результати розрахунків рівнянь лінійної регресії наведено в таблиці 3.

Параметри лінійності (див. рис. 2, 3, табл. 3) відповідають вимогам ДФУ на всьому діапазоні застосування аналітичної методики.

Правильність та прецизійність методики

Для перевірки правильності та прецизійності методики готували суміші з точно відомим вмістом АТC, які охоплювали діапазон застосування методики (з концентраціями 70-130 \% від номі- нальної). Відповідно до вимог ДФУ, розраховували такі критерії, як: систематична похибка $\delta$, \% (для правильності) та відносний довірчий інтервал $\Delta z$ (для прецизійності). Результати проведених розрахунків наведено в таблиці 4.

Як випливає з таблиці 4, прецизійність експериментальних результатів характеризується припустимим розкиданням відносно середнього і, відповідно, низьким стандартним відхиленням $S_{z}$ \% на всьому діапазоні концентрацій. Середня похибка методик (ठ) становить 0,02 \%, що характеризує достатню близькість середніх показників поглинання до номінальних значень.

Таблиця 3 - Метрологічні характеристики лінійної залежності 
Таблиця 4 - Результати вивчення правильності та прецизійності методики визначення аторвастатину

\begin{tabular}{|c|c|c|c|}
\hline \multirow[b]{2}{*}{ Модельний розчин } & \multicolumn{2}{|c|}{ Вміст АТС, \% } & \multirow{2}{*}{$\begin{array}{c}\text { Відношення знайденого до } \\
\text { введеного, } \\
Z_{i}=\left(Y_{i} / X_{i}\right) \cdot 100 \%\end{array}$} \\
\hline & $\begin{array}{c}\text { введено, } \\
X_{i}=\left(m_{i} / m_{r s}\right) \cdot 100 \%\end{array}$ & $\begin{aligned} & \text { знайдено, } \\
Y_{i}= & \left(A_{i} / A_{r s}\right) \cdot 100 \%\end{aligned}$ & \\
\hline$M_{1}$ & 69,97 & 69,82 & 99,79 \\
\hline $\mathrm{M}_{2}$ & 80,04 & 80,22 & 100,22 \\
\hline $\mathrm{M}_{3}$ & 89,93 & 89,97 & 100,04 \\
\hline $\mathrm{M}_{4}$ & 95,02 & 95,09 & 100,07 \\
\hline $\mathrm{M}_{5}$ & 100,05 & 99,95 & 99,90 \\
\hline $\mathrm{M}_{6}$ & 104,99 & 104,91 & 99,92 \\
\hline $\mathrm{M}_{7}$ & 110,23 & 110,11 & 99,89 \\
\hline $\mathrm{M}_{8}$ & 120,03 & 119,95 & 99,93 \\
\hline $\mathrm{M}_{9}$ & 130,03 & 130,09 & 100,05 \\
\hline \multicolumn{3}{|c|}{ Середнє значення, Z, \% } & 99,98 \\
\hline \multicolumn{3}{|c|}{ Стандартне відхилення, $S_{z} \%$} & 0,02 \\
\hline \multicolumn{3}{|c|}{ Відносний довірчий інтервал, $\Delta z=t(95 \% ; 8) \cdot S_{z}=2,3060 S_{z} \%$} & 0,05 \\
\hline \multicolumn{3}{|c|}{$\begin{array}{c}\text { Критичне значення для збіжності результатів } \\
\qquad \mathrm{z} \leq \max \Delta_{A S}=3,2 \%\end{array}$} & Виконується $(<3,2)$ \\
\hline \multicolumn{3}{|c|}{ Систематична похибка $\delta=|Z-100|, \%$} & 0,2 \\
\hline \multicolumn{3}{|c|}{ Критерій невизначеності систематичної похибки $\delta \leq \max \delta, \%$} & Виконується $(<0,05)$ \\
\hline \multicolumn{3}{|c|}{ Загальний висновок про методику } & Коректна \\
\hline
\end{tabular}

\section{Робасність методики}

Для вивчення робасності методики було обрано такий параметр, як стійкість аналізованих розчинів у часі (приготовлених за вищенаведеною методикою). У ДФУ не регламентується, через який проміжок часу після приготування розчину необхідно проводити вимірювання, тому ми обрали діапазон часу 2 год. Отримані результати наведено в таблиці 5. Розчини стабільні впродовж 100 хв (табл. 5).
Оцінка "озеленіння" аналітичної методики

При розробці спектрофротометричної методики визначення АТС у лікарському засобі було враховано принципи "зеленої" хімії. У таблиці 6 узагальнено результати оцінки "озеленіння" аналітичної методики.

Результати, наведені в таблиці 6, показують, що розроблена спектросотометрична методика визначення АТС у лікарському засобі $€$ відмінною відповідно до принципів “зеленої” хімії.

Таблиця 5 - Результати вивчення стабільності досліджуваних розчинів аторвастатину (1) та розчинів фрармакопейного стандартного зразка аторвастатину (2)

\begin{tabular}{||c|c|c|c|c|c|c|c|c||}
\hline \multirow{2}{*}{ № } & \multicolumn{6}{|c|}{ t, XB } & \multirow{2}{*}{ A cep } & \multirow{2}{*}{$\mathrm{RSD}_{\mathrm{t}}, \%$} \\
\cline { 2 - 9 } & 0 & 20 & 40 & 60 & 80 & 100 & & 0,56 \\
\hline 1 & 0,327 & 0,327 & 0,325 & 0,325 & 0,325 & 0,322 & 0,325 & 0,24 \\
\hline 2 & 0,508 & 0,505 & 0,505 & 0,505 & 0,505 & 0,505 & 0,506 & 0,24 \\
\hline
\end{tabular}

Таблиця 6 - Аналітична еко-шкала для оцінки “озеленіння” розробленої методики

\begin{tabular}{|c|c|}
\hline "Параметр & "Пенальті бали \\
\hline Розчинник: метанол & 1 \\
\hline Споживання енергії & 1 \\
\hline Профресійні шкідливості & 0 \\
\hline Загальна кількість пенальті балів & 7 \\
\hline Бал аналітичної еко-шкали & 93 \\
\hline
\end{tabular}

ВИСНОВКИ. 1. Розроблено просту надійну економічно есрективну "зелену" спектросротометричну методику визначення аторвастатину в субстанції та лікарському засобі.

2. Проведено валідацію аналітичної методики за такими параметрами, як специфрічність, лінійність, діапазон застосування, МВ та МКВ, правильність, прецизійність, робасність.
3. Показано можливість отримання коректних результатів у інших лабораторіях, оскільки розрахована повна невизначеність запропонованої методики становила 2,56 \%.

Джерела фінансування. Роботу виконано в рамках проєкту $0120 U 104201$ "Розробка оригінальних комбінацій антигіпертензивних засобів, їх аналіз та стандартизація". 


\section{СПИСОК ЛІТЕРАТУРИ}

1. Євтушенко О. М. Статини: фрармакоекономічні аспекти застосування препаратів групи інгібіторів ГМГ-КоА-редуктази / О. М. Євтушенко, В. Д. Немцова, В. В. Чайковська // Клініч. фрармація. - 2019. - 23, № 1. - C. 46-55.

2. Шуляк Л. М. Гіполіпідемічні лікарські засоби групи статинів в Україні: аналіз асортименту, економічної доступності та об'ємів споживання / Л. М. Шуляк, О. Г. Бердник // Conceptual options for the development of medical science and education: Collective monograph. Riga : Izdevnieciba "Baltija Publishing", 2020. - C. 656677.

3. Lippi G. Letter to editor - statins popularity: Aglobal picture to statins / G. Lippi, C. Mattiuzzi, G. Cervellin // Br. J. Clin. Pharmacol. - 2019. - No. 85. - P. 1614-1615.

4. European Pharmacopoeia (2020) European Pharmacopoeia ed. 10. - Access mode : https://www. edqm.eu/en/european-pharmacopoeia-ph-eur-10thedition

5. Development of a stability-indicating HPLC method for simultaneous determination of amlodipine besylate and atorvastatin calcium in tablets / H. M. Hafez, A. A. Elshanawany, L. M. Abdelaziz [et al.] // Austin J. Anal Pharm Chem. - 2014. - No. 1. - P. 1-11.

6. Gurram C. S. RP-HPLC method development and validation for the simultaneous estimation of atorvastatin, fenofibrate and ezetimibe in a pharmaceutical dosage form / C. S. Gurram // Biochemistry and Analytical Biochemistry. - 2015. - No. 4. - P. 1-4.

7. Concepts in development of fast, simple, stability indicating HPLC method for analysis of atorvastatin related compounds in tablets / M. Piponski, T. Bakovska Stoimenova, M. Piponska [et al.] // J. Anal. Pharm. Res. 2018. - No. 7. - P. 450-457.

8. Development of a novel, fast, simple HPLC method for determination of atorvastatin and its impurities in tablets / N. Shulyak, M. Piponski, S. Kovalenko [et al.] // Scientia Pharmaceutica. - 2021. - 89. - P. 1-16.

9. Kogawa A. C. Atorvastatin: A Review of Analytical Methods for pharmaceutical quality control and monitoring / A. C. Kogawa, A. E. Pires, H. R. Salgado // J. AOAC Int. - 2019. - 102 (3). - P. 801-809.

10. Development, validation and application of a novel HPLC-MS/MS method for the quantification of atorvastatin, bisoprolol and clopidogrel in a large cardiovascular patient cohort / R. M. Turner, V. Fontana, M. Bayliss [et al.] // Journal of Pharmaceutical and Biomedical Analysis. - 2018. - 159. - P. 272-281.

11. Raman spectroscopic investigation of atorvastatin, amlodipine, and both on atherosclerotic plaque development in APOE*3 Leiden transgenic mice / Sweder W. E. van de Poll, Dianne J. M. Delsing, J. Wouter
Jukema, [et al.] //Atherosclerosis - 2002. - 164. P. 65-71.

12. Миронова О. Ю. Спектрофотометричне визначення аторвастатину кальцію в таблетках / О. Ю. Миронова, С. О. Васюк // Актуальні питання фрармац. та мед. науки та практики : наук.-практ. журн. - 2015. - № 1. - С. 32-35.

13. Al-Adl S. M. Spectrophotometric determination of atorvastatin calcium and rosuvastatin calcium in bulk and dosage form using $p$-dimethylaminobenzaldehyde / S. M. Al-Adl, M. A. Lobna, A. M. Maha // Journal of Applied Pharmacy. - 2017. - No. 9. - P. 1-7. D

14. Alshabrawy A. Sensitive spectrophotometric determination of atorvastatin in pharmaceutical formulation by ion pair complexation with pararosaniline hydrochloride / A. Alshabrawy, A. Mostafa, N. Abotaleb // Journal of Advanced Pharmacy Research. - 2017. - No. 1 (4). P. $193-200$

15. Bernard S. New spectrophotometric method for the estimation of atorvastatin calcium and aspirin using urea as hydrotropic solubilizing agent, Hygeia. / S. Bernard, S. Rani, M. C. Babitha // Journal for Drugs and Medicines. - 2018. - No. 9 (2). - P. 11-19.

16. Method development for quantitative determination of seven statins including four active metabolites by means of high-resolution tandem mass spectrometry applicable for adherence testing and therapeutic drug monitoring / L. Wagmann, S. Hemmer, A. T. Caspar [et al.] // Clin. Chem. Lab. Med. - 2020. - No. 58 (5). P. 664-672.

17. Naseri A. Silver nanowires immobilized on goldmodified glassy carbon electrode for electrochemical quantification of atorvastatin / A. Naseri, M. R. HormoziNezhad, S. Shahrokhian Elham Asadian // Journal of Electroanalytical Chemistry. - 2020. - No. 876. P. 114-124.

18. Development and validation of spectrophotometric method for simultaneous estimation of valsartan and atenolol in binary mixtures: aplication to tablets analysis / K. Peleshok, O. Poliak, L. Kryskiw [et al.] // Pharmakeftiki. 2021. - 33, Issue I. - P. 52-60.

19. Державна Фармакопея України / Державне підприємство "Український науковий фрармакопейний центр якості лікарських засобів". - 2-ге вид. - Доп. 2. X. : Державне підприємство "Український науковий фрармакопейний центр якості лікарських засобів", 2018. - 336 c.

20. ICH (International Council of Harmonisation), Expert Working Group (2005). Validation of Analytical Procedures: Text and Methodology Q2(R1). [Електронний ресурс]. - Access mode : https://www.gmpcompliance.org/files/guidemgr/Q2(R1).pdf

\section{REFERENCES}

1. levtushenko, O.M. Nemtsova, V.D., \& Tchaikovsky, V.V. (2019). Statins: pharmacoeconomic aspects of the use of drugs of the group of HMG-CoA reductase inhibitors. Clinical Pharmacy, 23 (1), 46-55 [in Ukrainian].
2. Shuliak, L.M., \& Berdnyk, O.H. (2020). Hypolipidemic drugs of the statin group in Ukraine: assortment analysis, economic availability and consumption volumes. Conceptual options for the development of medical 
science and education: Collective monograph. Riga: Izdevnieciba "Baltiya Publishing" [in Ukrainian].

3. Lippi, G., Mattiuzzi, C., \& Cervellin, G. (2019). Letter to editor - statins popularity: A Global picture to statins. Br. J. Clin. Pharmacol, 85, 1614-1615.

4. European Pharmacopoeia. (2020). European Pharmacopoeia (10 th edn.). Retrieved from: https://www. edqm.eu/en/european-pharmacopoeia-ph-eur-10thedition

5. Hafez, H.M., Elshanawany, A.A., Abdelaziz, L.M., \& Mohram, M.S. (2014). Development of a stabilityindicating HPLC method for simultaneous determination of amlodipine besylate and atorvastatin calcium in tablets. Austin J. Anal Pharm. Chem., 1, 1-11.

6. Gurram, C.S. (2015). RP-HPLC method development and validation for the simultaneous estimation of atorvastatin, fenofibrate and ezetimibe in a pharmaceutical dosage form. Biochemistry and Analytical Biochemistry, 4, 1-4.

7. Piponski, M., Bakovska Stoimenova, T., Piponska, M., \& Trendovska Serafimovska, G. (2018). Concepts in development of fast, simple, stability indicating HPLC method for analysis of atorvastatin related compounds in tablets. J. Anal. Pharm. Res, 7, 450-457.

8. Shulyak N., Piponski M., Kovalenko S., Stoimenova T. B., Balkanov T., El-Subbagh H.I., Drapak I., Omotosho J.O., Logoyda L. (2021). Development of a Novel, Fast, Simple HPLC method for determination of atorvastatin and its impurities in tablets. Scientia Pharmaceutica, 89, 1-16.

9. Kogawa, A.C., Pires, A.E., \& Salgado, H.R. (2019). Atorvastatin: A Review of Analytical Methods for pharmaceutical quality control and monitoring. J AOAC Int., 102 (3), 801-809.

10. Turner, R.M., Fontana, V., Bayliss, M., Whalley, S., Castelazo A.S., \& Pirmohamed M. (2018). Development, validation and application of a novel HPLCMS/MS method for the quantification of atorvastatin, bisoprolol and clopidogrel in a large cardiovascular patient cohort. Journal of Pharmaceutical and Biomedical Analysis, 159, 272-281.

11. Van de Poll, Sweder W.E., Delsing, D.J.M., Wouter Jukema, J., Princen, H.M.G., Havekes, L.M., Puppels, G.J., van der Laarse, A. (2002). Raman spectroscopic investigation of atorvastatin, amlodipine, and both on atherosclerotic plaque development in APOE*3 Leiden transgenic mice. Atherosclerosis, 164, 65-71.
12. Myronova, O.Yu., \& Vasiuk, S.O. (2015). Spectrophotometric determination of atorvastatin calcium in tablets. Current Issues of Pharmaceutical and Medical Science and Practice, 1, 32-35 [in Ukrainian].

13. Al-Adl, S.M., Lobna, M.A., \& Maha, A.M. (2017). Spectrophotometric determination of atorvastatin calcium and rosuvastatin calcium in bulk and dosage form using p-dimethylaminobenzaldehyde. Journal of Applied Pharmacy, 9, 1-7.

14. Alshabrawy, A., Mostafa, A., \& Abotaleb, N. (2017). Sensitive spectrophotometric determination of atorvastatin in pharmaceutical formulation by ion pair complexation with pararosaniline hydrochloride. Journal of Advanced Pharmacy Research, 1 (4), 193-200.

15. Bernard, S., Rani S., \& Babitha M.C. (2018). New spectrophotometric method for the estimation of atorvastatin calcium and aspirin using urea as hydrotropic solubilizing agent, Hygeia. Journal for Drugs and Medicines, 9 (2), 11-19.

16. Wagmann, L., Hemmer, S., Caspar, A.T., \& Meyer, M.R. (2020). Method development for quantitative determination of seven statins including four active metabolites by means of high-resolution tandem mass spectrometry applicable for adherence testing and therapeutic drug monitoring. Clin. Chem. Lab. Med., 58 (5), 664-672.

17. Naseri, A., Reza Hormozi-Nezhad, M., \& Shahrokhian Elham Asadian, S. (2020). Silver nanowires immobilized on gold-modified glassy carbon electrode for electrochemical quantification of atorvastatin. Journal of Electroanalytical Chemistry, 876, 114-124.

18. Peleshok K., Poliak O., Kryskiw L., Agyemang F. Sarpong, Zarivna N., Korobko D., Zahrychuk H., Horlachuk N., Sverstiuk A., Levytska L., Logoyda L. (2021). Development and validation of spectrophotometric method for simultaneous estimation of valsartan and atenolol in binary mixtures: aplication to tablets analysis. Pharmakeftiki, 33 (1), 52-60.

19. (2018). State Pharmacopoeia of Ukraine. Supplement 2. Ed 2. Kharkiv: Derzhavne pidpryiemstvo "Ukrainskyi naukovyi farmakopeinyi tsentr yakosti likarskykh zasobiv" [in Ukrainian].

20. (2005). ICH [International Council of Harmonisation], Expert Working Group Validation of Analytical Procedures: Text and Methodology Q2(R1). Retrieved from: https://www.gmp-compliance.org/files/guidemgr/ Q2(R1).pdf 


\section{DEVELOPMENT OF SPECTROPHOTOMETRIC METHOD FOR DETERMINATION OF ATORVASTATIN IN TABLETS}

\section{Summary}

Introduction. Atorvastatin is widely represented in the pharmaceutical market of Ukraine hypolipidemic agent for the treatment of hyperlipidemia and prevention of cardiovascular system diseases. Many procedures are known for assay of atorvastatin, however, many of them have limitations due to the using of harmful reagents, time consuming, heating, extraction etc.

The aim of the study - to develop simple, cost-effective, UV-spectrophotometric method for the estimation of atorvastatin in tablet dosage form that are available on the Ukrainian market according to the principles of "green" chemistry.

Research Methods. The studies were carried out on Shimadzu UV-1800 spectrophotometer (Japan), electronic laboratory balance RAD WAG AS 200/C, ultrasonic bath Sonorex Digitec DT100H, measuring glassware class A. Atorvastatin calcium salt trihydrate CRS (Sigma-Aldrich $\geq 98 \%$, HPLC), methanol R (Honeywell Riedel-de Haen $^{\mathrm{TM}}, 99.9$ \%), Atorvastatin-Teva tablets, 10 mg No.10 (Teva, Israel), batch No.19939.

Results and Discussion. For the development of determination procedure of atorvastatin by direct UV spectrophotometry, an intensely expressed absorbance maximum of the latter at $247 \mathrm{~nm}$ was selected. Correctness of the analytical procedure was confirmed by calculating its complete uncertainty (2.56 \%). The linear dependence in the range of $8-40 \mathrm{mg} / \mathrm{ml}$ was obtained. The specificity of the method is proved by the absence of absorbance at the analytical wavelength in solutions of placebo tablets. The precision of the experimental data was characterized by a low standard deviation in the studied concentration range of API and the systematic error was $0.02 \%$. In robustness studies it was found the stability of solution absorbance over time for 100 minutes. According to the analytical eco-scale, the method belongs to the "Excellent green analysis".

Conclusion. A method for UV spectrophotometric determination of atorvastatin in tablets $\left(\lambda_{\max }=247 \mathrm{~nm}\right)$ was developed. The complete uncertainty of the developed method was calculated. According to such validation parameters as linearity, precision, accuracy and robustness, the method is correct.

KEY WORDS: spectrophotometry; atorvastatin; determination; validation; analytical eco-scale.

Отримано 16.11.21

Адреса для листування: Л. С. Криськів, Тернопільський національний медичний університет імені I. Я. Горбачевського мОз України, майдан Волі, 1, Тернопіль, 46001, Україна, e-mail: kryskiw@tdmu.edu.uа. 